\title{
İsnâdın Satır Araları
}

Muhammed Enes Topgül

Marmara Üniversitesi İlâhiyat Fakültesi Yayınları, İstanbul, 2018, 220

sayfa

ISBN 9789755484716

Sağlam bir isnad bilgisi hadisle iştigal edenlerin en çok ihtiyaç duyduğu şeylerden biridir. Bir hadisi okuyup da onun senedindeki râvilerin birbirleriyle ilişkilerini, zamanını, mekânını gözünde canlandırabilmek, varlığından bile haberdar olunmayan bir kitap hakkında bilgi edinmek yahut şimdi dünya çapında tanınan bir âlimin ilim tahsiline başladığı gençlik yıllarından bir sahne yakalamak herkesin kârı olmayıp yıllar süren hadis okumaları ve isnad araştırmalarıyla elde edilebilecek bir beceridir. İsnad çalışmak dışarıdan çok soğuk, cazip tarafı bulunmayan bir iş gibi görünür. Ama isnadın kıymetini bilenler, onu sadece hadisleri günümüze ulaştıran bir araç olarak görmezler ve isnad incelemelerinin aynı zamanda ilim tarihi yazmak için de verimli bir alan olduğunu bilirler. 1200 yıl önceki bir muhaddisin sıradan saydığg için tesadüfen isnada kaydettiği ve aynı sebeple kaynağı unutulmuş bir bilgi, isnada nasıl bakacağını bilenlerin nazarında önem arzedebilir. Ne var ki bu kabil bilgilerin kaynağını, yerini, zamanını, anlamını araştırmak büyük emek ister. Zira dışarıdan bakıldığında karşımızda çoğu zaman kimin neyi söylediği bilgisinin dahi bulunmadığı, yedi sekiz ismin peş peşe sıralandığı bir senedden başka bir şey yoktur. Geçmişte âlimler isnaddaki unsurları yılların verdiği tecrübeyle ve içinde bulundukları ilmî ortamın katkısıyla biliyorlardı. En azından bilmedikleri zaman nereye başvuracaklarını biliyorlardı. Günümüzde bu tecrübe büyük oranda kaybolmuş olmakla birlikte, teknolojinin verdiği fırsatlar sayesinde hâlâ isnad üzerinden verimli araştırmalar yapmak mümkündür.

Muhammed Enes Topgül, Ahmed b. Hanbel'in meşhur eseri Müsned'den seçtiği 3700 kadar senedi inceleyerek kaleme aldığ̀ İsnâdın Satır Araları’nda, okuyucuya senedleri okumak konusunda faydalı bir şeyler söyleyeceğini daha kitabın isminden belli ediyor. Müellif kitaba başlık olarak uygun bulduğu "satır arası" tabirini nedense içeride pek kullanmamış, bunun yerine daha soğuk duran "isnad içi bilgi" ifadesini tercih etmiş (açıklaması için bk. s. 11). Belli ki teknik gerekçelerle böyle düşünülmüş ve zamanla bunun bir terim haline geleceği umulmuş, ama satır arası tabiri kullanılsa daha iyi olabilirdi. Hem okuyucunun diğer alanlardan ve metinlerden (bambaşka yönleriyle de olsa) tanıdığı hem de meramı gayet güzel ifade eden bir tabir olurdu. 
Eser, adından da anlaşılacağ esas maksadı olan hadislerin sağ salim günümüze ulaştırılmasıyla ilgili yönünü değil, görünmeyen yüzünü, kastetmediği ama içerdiği dolaylı bilgileri incelemeyi amaçlamaktadır. Senedler günümüzde kitaplarda kayıtlı oldukları şekliyle ilk ve esas maksadı zaten yerine getirmiş durumdalar; ancak onların satır araları hâlâ okunmayı beklediğinden yazar buraya odaklanmayı tercih etmiş.

Topgül'ün yaptıklarını iki gruba ayırmak mümkündür: $\mathrm{O}$ ilk olarak satır arası notları sayesinde râvilerin "kimlikleri", "ilişkileri ve güvenilirlikleri", "hadisleri aldıkları yer ve zaman" gibi konulara dair bilgi bulunabileceğini göstermektedir (tırnak içindeki ibareler aynı zamanda üç bölümlük eserin sırasıyla birer bölümünün konusudur). Ancak müellifin okuyucuyu bıktırmak pahasına, her başlık altında defalarca değindiği bir husus, onun esaslı bir hedefinin daha olduğunu gösteriyor: Cerh-ta'dîl literatürünün başlang1cını şimdi bildiğimizden elli-altmış yıl kadar geri almamız gerektiğine dikkat çekmek! Yazarın bu konudaki en önemli dayanağı, cerh-ta'dîl eserlerinin ilk meşhur örnekleri yazılmadan önce bu bilgilerin isnadların satır aralarına yedirildiği gerçeğini farketmesidir. Sadece Ahmed b. Hanbel'in Müsned’i esas alınarak, yani çok sınırlı bir kaynak üzerinden gerçekleştirilen fakat türünün erken ve önemli örneklerinden biri olacağında şüphe bulunmayan çalışması sayesinde müellifin ulaştı̆̆ı bu yargı, bir literatürün yeterince dikkat edilmeyen kaynağına işaret etmiş ve bu literatürün tarihî gelişimi için yeni bir bakış açısı sunmuş olması bakımından önemlidir (müellifin usanmadan okuyucuya hatırlattığ 1 bu hususa dair örnekler için bk. s. 83, 85, 88-90, 96-99, 105-116, $125,127-128,132-134,136,139,145,147,151-152,194-195)$. Ancak bu yarg1 sonraki aşamalarda, "Bugün elimizdeki cerh-ta'dîl bilgilerinin ne kadarı satır arası bilgilerden oluşuyor, bunun yekünü nedir?" gibi bir soru çerçevesinde tekrar değerlendirilmelidir.

"Satır aralarındaki bilgiler kimler tarafından oraya konuldu?" sorusu müellifi eserde çok meşgul eden bir diğer meseledir. Baştan belirtmek gerekir ki bu sorunun gündeme geldiği her örnekte doyurucu cevap bulmak ne yazık ki artık hiç kimse için mümkün değildir. Dolayısıyla kimi örneklerde cevabın bulunamamış olması müellifin kusuru değildir. Ayrıca eser türünün ilk örneklerinden olduğu için onun açtığ yoldan ilerlemeyi düşünen sonraki araştırmacılar bu konuda muhakkak yeni şeyler söyleyeceklerdir. O zaman da kapıyı ilk açan olma şerefi yazara ait olacaktır.

Müellifin bazı yerlerde ikna edici cevaplara ulaşmak için ciddi gayret sarfettiği, gerek Müsned'den seçtiği örneklerden gerek bunları diğer hadis kitaplarıyla karşılaştırmak suretiyle (bk. s. 29) sergilediği ince işçilikten 
anlaşılmaktadır. Bunların eserde çok örneği bulunduğundan tek tek işaret etme gereği duymuyoruz (güzel bir örnek için bk. s. 177-178). Ancak cevaplarının her zaman ikna edici olduğunu söylemek mümkün değildir. Bazı yerlerde bütün ihtimallerin tartışılmamış olması buna örnek verilebilir: Mesela s. 70-71'de adı geçen Şimr hiç gündeme alınmamış; Ahmed b. Hanbel'in adının geçtiği bazı senedlerin satır aralarının hadis kitaplarında niçin küçük de olsa farklılıklar ihtiva ettiği hususunda, onun ilgili hadisi rivayet ettiği uzun yıllar boyunca her seferinde aynı şekilde rivayet etmemiş olabileceğinin, dolayısıyla farklılıkların başkalarından değil, bizzat Ahmed b. Hanbel'in ders yapış tarzından kaynaklanabileceği ihtimali üzerinde yeterince durulmamış; bir râvinin üzerinden müphemliği-belirsizliği kaldıran ifadelerin sahibi aranırken, ona en yakın talebe bazı örneklerde (s. 72, 85) beklenenden daha çabuk göz ardı edilmiştir. Diğer yandan müellifin, senedlerdeki erken dönemlere ait açıklamaları geç dönem açıklamalarıyla kıyaslarken, cerh-ta'dîlin tabir caizse amatör bir uğraştan bir mesleğe ve ilim dalına dönüşü sürecini dikkate alması da makul bir izah tarzıdır (s. 100). Yazarın yine çaresiz kaldığı, ancak bunu yeterince açık biçimde dile getirmediği bir mesele de şudur: Bir hadis kitabını okurken onun senedlerinin satır aralarındaki bilgileri kimin koyduğunu görmenin yollarından biri, elbette kitabın yazma nüshalarını incelemektir. Bu, konuyla ilgili okuyucuların aklına gelecek ilk ihtimallerdendir. Müellif, yazma nüshaların bu konudaki önemine eserde nispeten geç bir yerde (ilk olarak s. 59'da) ve kısaca işaret etmiştir. Ancak erken dönem eserlerine ait yazma nüshaların bu kabil karşılaştırmalara imkân verecek bollukta elimizde bulunup bulunmadığı hususu, üzerinde daha fazla durulmayı hak etmektedir. Kanaatimizce daha eserin girişinde, kaynak olarak Müsned'in seçildiğini gösteren kısımda bu konuya değinilmeliydi. Böylece okuyucu, başka çare olmadığ i çin günümüzdeki matbu nüshalardan hareketle çalışmanın yapıldığını bilerek eseri okurdu.

Basmakalıp bilgilerimiz, ön kabullerimiz veya mensubu olduğumuz bir grubu savunma dürtüsü bazan gözümüzün önündeki şeyleri farketmemize mani olur. Yazar da eserin kimi yerlerinde bu duruma düşmüşe benziyor: Mesela bir yerde Ahmed $b$. Hanbel'in hocalarından aldığ senedler üzerinde oynama yapabildiğine dair bir örnek verirken (s. 33), başka bir yerde aynı Ahmed b. Hanbel'in bilgi üzerinde niçin oynama yapmış olamayacağını açılama sadedinde, "Hadisçiler hocalarından aldıkları bilgiyi değiştirmezler” genel kuralına sığınmıştır (s. 44-45). Doğrudur, genel kural olarak muhaddisler böyle davranır, ancak isnadın satır aralarını okuma iddiasındaki bir kitapta, genel geçer kurallara uymayan örneklerin ön plana çıkarılması ve bunların kaynaklarının, yerinin, zamanının, sebeplerinin ve sonuçlarının 
bulunması beklenmektedir. Bu yüzden de Ahmed b. Hanbel'in bilgiyi değiştirmediğini değil, değiştirdiğini gösteren örnekler bu kitap için daha önemlidir. Bilginin değiştirildiği örnekte Ahmed $b$. Hanbel'in senedde adı geçen Ebû Hanîfe'yi ismiyle anmak istemediğinden "Ebû Fülâne" dediği hatırlanacak olursa bu durum daha iyi anlaşılır.

Satır arası bilgilerle haşır neşir olmanın doğal bir sonucu olarak müellifin de bazan isnadın orijinalinde olmayan bilgiler verdiği, yani satır arasına ziyade yaptığı görülür. Bir yerde "Örneğin ismi isnadda mutlak olarak Mûsâ şeklinde zikredilen râvinin Mısırlı Ebû Abdurrahman Mûsâ b. Ali (ö. 163/780) olduğu şöyle tasrih edilir: ..." diyen müellifin bunu delillendirmek için verdiği orijinal metne bakınca sadece Mûsânın Mûsâ b. Ali olarak açıklandığını görürüz. Onun "Mısırlı" ve "Ebû Abdurrahman" olduğuna dair bilgi Topgül tarafından buraya dercedilmiştir. Böylece satır arası yapmanın aslında kötü bir şey değil, açıklayıcı bir ameliye olduğunu bir defa da müellif üzerinden tecrübe ederiz.

Eserin kimi yerlerinde görülen, daha iyisi bulunabilecek ifade tercihleri (s. 22, 88, 109, 118, 123, 124, 145, 174), cümle düşüklükleri (s. 21, 85, 87, 117, $118,127)$ ve tashih gerektiren noktalar (s. 36, 113, 115, 118, 124, 146, 147, 178, $188,191)$ bir bütün olarak eserin okunmasına mani olacak boyutta değildir. Ancak küçük bir not olarak müellifin 41. sayfadaki 50. dipnotta kullandığ1 "dikkatler" kelimesine işaret ederek, tarama sözlüklerinde kelimenin bu şekilde kullanıldığına dair hiçbir örnek bulamadığımızı belirtelim.

Müellifin de farkında olduğu üzere bazı yerlerde çok az örnek üzerinden genel yargılara ulaşılmıştır (s. 87). Böylesi durumlarda daha fazla örneğe ve çalışmaya ihtiyaç olduğu hususunda kendisiyle hemfikiriz ve bunu müstakbel araştırmacılar için bir işaret olarak yorumluyoruz. Bu eserde kısaca değinilen yahut onu okurken zihinde uyanan ve sonraki benzer araştırmalarda üzerinde daha fazla durulması gereken birçok soru vardır: Senedlerdeki bilgileri bugün orada gördüğümüz şekliyle kaydedenler kimlerdir? Bu bilgileri kaydetme ameliyesinin azaldığı ve çoğaldığı dönemler yahut coğrafyalar hangileridir ve neye istinaden böyle olmuştur? Genellikle senedlere (yahut hocalarından aldıkları bilgilere) hiç dokunmadan onları aktaran muhaddisler için bir senede müdahale etmek ne zaman meşru hale gelir? Ahmed b. Hanbel'in en yakınındaki isim olarak oğlu Abdullah, babasının eserinin günümüzdeki şeklini almasında ne kadar etkili olmuştur? Abdullah’n bütün müdahalelerini görme imkânına sahip miyiz, yoksa onun bazı müdahalelerini hiçbir zaman farkedemeyecek miyiz? Ahmed b. Hanbel'in eserlerinin birbiriyle etkileşimi nasıldır ve hangi boyuttadır? Acaba Abdullah, babasının elİlel'i ile Müsned' indeki (yahut okuduysa Ebû Dâvûd'un Suâlât'indaki) bilgileri 
karşılaştırıp, yerine göre bunlara müdahaleler yapıyor muydu? (s. 140, 141 ve 142'deki örneklere bu gözle bakılabilir). Bugün el-ïlel ile Müsned'de aynı hadis üzerinde birbirini doğrulayan yahut yanlışlayan kaynağı belirsiz bilgilerden hangilerinin Ahmed b. Hanbel'e, hangilerinin Abdullahin müdahalelerine ait olduğunu anlamanın bir yolu kalmış mıdır? Bu eser üzerinden Müsned’e bakınca bir manzara oluşuyor. Peki diğer meşhur kitapların, mesela Kütüb-i Sitte müelliflerinin senede müdahale konusundaki tutumları nasıldı? Birbirleriyle kıyaslandıklarında nasıl sonuçlar ortaya çıkar? Son olarak: İsnadın satır aralarını okuduğumuz gibi, metinlerin de satır aralarını okusak acaba nelerle karşılaşırız?

Halit Özkan, Doç.Dr. İstanbul Şehir Üniversitesi İslami İlimler Fakültesi

ORCID 0000-0003-2829-6010

DOI 10.26570/isad.754351 